\title{
Don't Give Up the Adoptee: The Research of Adoption Dissolution in Taiwan
}

\author{
Emily Yueh-Mi Lai \\ The Department of Social Work, Tzu Chi University, Taiwan \\ *Corresponding Author: emily328@mail.tcu.edu.tw
}

\begin{abstract}
It has been observed that increasing the rate of adoption dissolution compromises children's rights. This study set out to investigate adoption dissolution including its causal factors and risk factors. It also set out to identify coping strategies to help avoid the situation leading to adoption dissolution. The study adopted qualitative and quantitative methodology to collect and analyze data. The research methods included a questionnaire survey, focus group discussions and interviewing. 44 questionnaires of adoption dissolution were collected and 44 interviews and some focus group discussions were conducted. The findings revealed a range of risk factors of adoption dissolution including adoptee characteristics (e.g. older age, emotional and behavioral disorder, sibling separation , special needs.); adopter family characteristics (e.g. their elders forcing them to adopt kids, too high expectation for child's performance, lack of parenting skills, lack of caring experience, an unstable marriage, pregnancy after adoption, step parent adoption); and agency characteristics(e.g. unprofessional in matching, insufficient service quality and assistance, unfit family needs, inadequate information). The research found that most of minor child adoption dissolution occurs in private adoption contexts. The perspective of adoption is still conservative and traditional, and focuses on adults' themselves, not concerns the best interests of the child. Thus, Taiwan' s Government and adoption agencies should actively provide assistance for adoption, and make post-adoption supportive services available and accessible to protect the best interests of the child.
\end{abstract}

Keywords Adoption, Adoptee, Birth Parents, Adoption Dissolution, The Best Interests of the Child

\section{Introduction}

It has been observed that increasing the rate of adoption dissolution compromises children's rights and the best interests of the child (Schwartz, 2006). Unfortunate events relating to adoption dissolution have occurred in Taiwan. For example, in 2008 in Taipei, a physician and his wife who adopted an 11 years old boy for 4 years after he had been in orphanages for 7 years. Threw him out one midnight and went on to claim adoption dissolution. Newspapers disclosed the incident the following day and the community was shocked as to why the adoptive parents treated the boy in such a terrible way (Liu, 2008).

Parens patriae should protect the children's rights and the best interests of the child when they have to be or have been adopted. The government should implement national parental rights to advocate the correct adoption philosophy and also provide parenting courses to support adoptive parents so as to help them become suitable parents (Lai, 2010; The Swedish National Board of Health and Welfare, 2009).

This study had three aims. First, it sought to investigate adoption resolution and the reasons why it occurs. Second, it sought to explore the risk factors of adoption dissolution and third, it aimed to identify coping strategies that would help avoid adoption dissolution.

\section{Literature Review}

\section{The change of adoption concept and system}

Substitute child welfare includes adoption, foster care and institution care as well as, all sort forms of out of home care (Pecora, 2006; Coakley \& Berrick, 2008). Out of home care originated from Elizabeth Poor Law which stipulated that employers must take care of children until they are 21 years old. This apprenticeship and indenture system although exchanged by children's labor, provided at least basic care for children. Research notes the influence from Europe to the United States and records that in 1853 American Pastor Charles Loring Brace recognized the gravity of urban crime resulting from the increase in the number of poor, uneducated, homeless youth. He therefore launched the Free Foster Home Movement. Through this he helped the children to work and sent them by trains from New York to the West and South. These so-called orphan trains became the first out of home service in the United States (Pecora \& Maluccio, 2000; Scherr, 2001). 
The following 1989 Convention on the Rights of the Child (CRC) is pertinent as stated in the following articles:

- Article 20: A child temporarily or permanently deprived of his or her family environment, or in whose own best interests cannot be allowed to remain in that environment, shall be entitled to special protection and assistance provided by the State.

- Article 21: (a) Ensure that the adoption of a child is authorized only by competent authorities who determine, in accordance with applicable law and procedures and on the basis of all pertinent and reliable information, that the adoption is permissible in view of the child's status concerning parents, relatives and legal guardians and that, if required, the persons concerned have given their informed consent to the adoption on the basis of such counselling as may be necessary; (b) Recognize that inter-country adoption may be considered an alternative means of child's care, if the child cannot be placed in a foster or an adoptive family or cannot in any suitable manner be cared for in the child's country of origin.

The two important bills in the US, the Adoption Assistance and Child Welfare Act of 1980) and the Adoption and Safe Families Act of 1997, emphasize the importance of bonds and biological blood between birth parents and children. Out of home care should be the last choice, unless the family situation is inappropriate. The State should be concerned about the child's safety, well-being, family integrity and family preservation and other issues (Faller, 2000). Therefore, the US government encouraged and initiated family reunification programs, provided birth family home intensive time-limited services, to assist the foster care child to return home as soon as possible. On the other hand, for children who could not return home, it also took into account the children's safety and best interests of children and provided a permanent placement service (Maluccio, 2000). Adoption has become an alter birth Child Welfare Policy and Services (Coakley \& Berrick, 2008).

Adoption Services social workers should assist adoptive families to deal with problems with children, and help children to build attachment with adoptive parents (Schooler \& Atwood, 2008; Gray, 2002). Adoption Services emphasize that adoptive parents are psychological parents, because they provide day and day care, mental competency to the child, even though there is no physiological bonds (Schwartz, 2006; Triseliotis, Shireman, \& Hundleby, 1997). Legislative philosophy emphasizes the safety and protection of children's growth and preservation of the original family (Adoption Assistance and Safe Families Act, 1997) (Faller, 2000). Further, international adoption emphasizes the need to avoid discrimination on cultural, religious and racial grounds (Cruz, 2011; Masson, 2009; Schooler \& Atwood, 2008).

\section{The change of the Adoption Act in Taiwan}

Chinese adoption system has existed for a long time, having originated in the Western Zhou Dynasty patriarchal system, for the following stated purposes- "for the ancient", "for the family", "for the parents"(Lee, 2002). The so-called "adoption", according to Taiwan Civil Law Article 1072 is explained as follows: Where a person adopts the child of another as his own child, the adopter is called the adoptive father or adoptive mother and the person adopted is called the adopted son or adopted daughter. But as the adoption evolution has progressed, the reasons for adoption have become diverse, not only for the interest of the adoptee, but also taking into account the best interest of the children (Lin, 1996; Wang, 2007; Deng, 2007).

The change in the Adoption Act in Taiwan demonstrated an important evolution recently, focused on the best interests of the child, as in the following regulations:

A. 2007- Adoption shall be effected in writing and petitioned for the court's approval(Civil Law §1079)

2007- The court shall approve the adoption of the minor based upon the best interest of the adoptive child(Civil Law §1079-1)

B. 2007-A minor of younger than seven years of age shall make the declaration of intention and accept the declaration of intention through his/her statutory agent when he/she is to be adopted. A minor older than seven years of age shall obtain the consent of his/her statutory agent when he is to be adopted(Civil Law §1076-2)

C. 2011- Order the adopter to live with the children and youth for a certain period. During the period of living together, the adopter will be responsible for the children and youth's interests and needs (The Protection of Children and Youths Welfare and Rights Act\$17).

D. 2011- The adoption matching services agency will conduct the necessary interviews for the adoption before accepting the consignment, and make an assessment report. (The Protection of Children and Youths Welfare and Rights Act\$17)

E. 2011- Parents and guardians unable to take responsibility for their children's maintenance and are considering adoption will entrust the adoption matching services agency to search for an appropriate adopter, in private adoptions only close kinship relatives and stepfamily adoption(The Protection of Children and Youths Welfare and Rights Act\$16).

F. 2011- Only adoption matching services can undertake the placement and education of children and youth by incorporated foundations and public/private institutes subject to the approval of the authorized agency(The Protection of Children and Youths Welfare and Rights Act $\$ 16)$.

G. 2011- In accordance with the Hague Convention on international adoption considers the national adopter as priority (The Protection of Children and Youths Welfare and Rights Act\$16).

H. 2011- The court will adapt the measures before confirming the adoption of children and youth for the court's reference. For example, order the adopter to 
attend preparation courses for parental education, mental appraisals, drug and alcohol tests or the necessary issues that protect the best interests of the children and youth; any expenses will be at the cost of the adopter(The Protection of Children and Youths Welfare and Rights Act $\$ 16)$.

I. 2007- The relationship between an adopted child and his adoptive parents may be terminated by mutual agreement of the parties. The termination provided in the preceding paragraph shall be made in writing. Where the adoptive child is a minor, the termination shall be petitioned to the court. The court's approval of the adoption under the preceding paragraph must be based on the best interest of the child. (Civil Law $\S 1080)$

J. 2007- Where either party, the adoptive parents or the adoptive child, meets one of the following conditions, the court can terminate the adoption based on the petition of the other party, administrative authority or interested person:(1) Where the party has abused and grossly insulted the other party;(2) Where the party abandoned the other party;(3) Where the party committed a crime intentionally and is sentenced to more than two years imprisonment without probation; or(4) Where there is other grave reason that makes it hard to maintain the adoption relationship. Where the adoptive child is a minor, the court shall terminate the adoption based upon the best interest of the adoptive child.. (Civil Law §1081)

\section{Foreign Studies in Adoption Dissolution Risk Factors}

Research of Child Welfare Information Gateway has shown that the average rate of adoption disruption was $10 \%$ $-25 \%$ in the United States. The older the adoptive child with special needs, the greater the risk of disruption. Child Welfare Information Gateway (2004) noted that the rate of adoption dissolution was roughly estimated at $1 \%-10 \%$. Adoption and termination of the greatest difficulties is due to the lack of access to adoption information and assistance with the associated costs.

\section{Child Characteristics}

\section{Older child}

The older the children who were adopted the greater the probability of failure (Rosenthal, Schmidt \& Conner, 1988). Barth \& Miller (2000) explain the situation of the adopted adolescent or older children who may have been older when they left the birth family. They may have a strong attachment with their birth family; or maybe they may have been abused and neglected by their birth family. Older children may find it difficult to adapt to new problems in the new family, because of prior experience with foster care or adoption (McCreight, 2002). Therefore, it is necessary to provide intensive in-home adoption preservation services, to assist adoptees in adapting to their new family. The success of adoption will lead older children and their adoptive parents to have a positive experience. In contrast, it would be particularly painful if older children fail to find adoptive parents. Therefore, adoption preservation services are very important (McRoy, Lynch, Chanmugam, Madden \& AyersLopez, 2009; Barth, \& Berry, 1991).

\section{Emotional and behavioral problems (Festinger, 2002)}

Birth family crises are likely to cause child emotional and behavioral problems such as excessive sexual performance, defiance, cruelty, bodily injury, withdrawal behavior, attachment difficulties, hyperactivity, etc. Children who had suffered sexual abuse were found to specially experience excessive sexual performance and have a strong attachment relationship with the birth mother. In this regard it was easier to maintain a high failure adoption rate (McCreight, 2002; Barth \& Miller, 2000; McDonald, Lieberman, Partridge \& Hornby, 1991).

\section{Sibling adoption situation}

The probability of adoption failure was low, when siblings were adopted at the same time or by the same adoptive family (Barth, Berry, Yoshikami, Goodfield \& Carson, 1988).

\section{Child with special needs}

This generally refers to the special needs of older children (generally more than four years old), the developmental delays, the child's disability, child emotional and behavioral problems, placing siblings together (Rosenthal, 1993). For the special needs of children, girls' adoption dissolution rate is relatively higher than that of boys (Rosenthal, Schmidt \& Conner, 1988). For the adoption of children with special needs, if the government provided adoption assistance this would reduce the failure rate of adoption dissolution (McDonald, Lieberman, Partridge \& Hornby, 1991).

Westhues \& Cohen (1990) indicated that there was a higher adoption dissolution rate for children on special needs adoptions compared to the general adoption of a child. Their study found that if the adoptive father played a key role, that is, was actively involved in parenting, had the ability to assist and support the adoptive mother, even if the child was a special needs adoption, the stability of the adoption could be maintained.

\section{Birth Family Characteristics}

Birth parents' characteristics, such as birth mothers with alcohol and drug problems, can easily produce physiological effects in children, causing difficulties in health and care, and resulting in easier adoption dissolution (Barth \& Miller, 2000).

\section{Adoptive family characteristics}

1. The experience of foster family

Barth, Berry, Yoshikami, Goodfield \& Carson researched 
adoption family in Northen California 1980-1984, and found that most of the adoption families were foster families, and consequently adoption dissolution rate dropped to $10.2 \%$. A different study also found a foster family which later became an adoptive family, resulting in a lower failure rate (McDonald, Lieberman, Partridge \& Hornby, 1991). Therefore, where there is no experience of foster care, where adoptive parents are too young, and lack the warmth of character, there is a higher rate of adoption dissolution (Barth \& Miller, 2000; Coakley \& Berrick, 2008).

\section{The adoptive parents' education}

Some studies have found that where adoptive mothers have higher levels of education, high school or specialist qualifications, there are high probabilities of failure rate in adoption dissolution (Barth, Berry, Yoshikami, Goodfield \& Carson, 1988; Barth \& Miller, 2000). Coakley \& Berrick (2008) explained that first, the adoptive mother with higher level education is more likely to have a job, so she has to work out of home. If the adoptive father and mother have less time at home, caring for the adopted child seems more challenging. Two, an adoptive mother with a higher level education is more likely to enquire about the children's intellectual performance. If the adopted children cannot reach their standards, the children would be frustrated and there would be friction in the family.

\section{The previous relationship between the adoptive family and the adoptee}

Adoption strangers, a situation where the adopter and adoptee originally did not know each other, results in a higher rate of adoption dissolution (Barth \& Miller, 2000). The adoption is more stable, if they are relatives (Coakley \& Berrick, 2008).

Stepfamily adoption has become a major adoption type in Taiwan (Chen \& Wang, 2003; Jiang, 2011). According to Jiang's study (2011), following the proposed marriage between step parents and birth parents, and if it is the wishes of step parents and the birth parents, the social worker visits and suggests based on "biological parents and step-parents having been married," that because the "stepparents and stepchildren have been living together for some time, this is a good relationship ". Therefore, the step-parent will adopt the child when the parents are married, and adopt dissolution when the parents are divorced. This view of adoption is still conservative and traditional, and focuses on adults' themselves. The Government and adoption agencies should actively provide assistance for adoption, and make available and accessible post-adoption supportive services to protect the best interests of the child (Lai, 2014b).

\section{Agency's characteristics}

\section{The matching adoption professional}

Generally with traditional matching adoption services, the matching adoption agency will provide the prospective adoptive parents with some children on the waiting list according to factors, such as, gender, age, race, mental ability, special needs status, and the child's physical and medical etc., sometimes accompanied by photos of children. This is followed by more matchmaking through social work assessment, to determine if the prospective adoptive parents and the adoptee status are a match. This process needs to be tried in the context of special needs children to match their needs to adoptive parents' parenting abilities. Therefore, some successful organizations developed questionnaires, test scales and structured interviews for prospective adoptive parents, in order to understand the real circumstances of adoptive parents. Inappropriate matchmaking during the matchmaking process and the social worker's assessment may also increase the rate of adoption dissolution (Valdez \& McNamara, 1994).

\section{Service quality - the information provided}

The adoptive parents will only give positive information, in order to increase the chance of adoption, but will not mention the real problem with the child and any negative previous historical data. The insufficient information and the lack of service delivery will lead to an increase in the rate of adoption dissolution (Barth \& Miller, 2000).

\section{Service quality}

Long service time and delays in the adoption process, will increase failure. Also, the quality of the family report or home study will affect the success of adoption (McDonald, Lieberman, Partridge \& Hornby, 1991).

\section{Professional and ethical work of agencies}

Agency staff's professional and ethic are very important. The adoption dissolution could occur due to factors such as agency worker excessive commitments to clients (Barth \& Miller, 2000).

\section{Institutional stability of staff}

Adopted parents and adoptees still need some help to overcome the post- adoption stress and challenges (Foli \& Thompson , 2004). A high turnover of adoption services staff, is likely to result in failure of adoption (Festinger, 2002).

\section{Research Methods}

This study adopted qualitative and quantitative methodology to investigate this phenomenon. Data was collected through field observations, a questionnaire survey, in-depth individual interviews and professional focus groups. A total of 44 questionnaires of adoption dissolution were collected. Focus group and interviewing were carried out with 44 interviewees including 1 adoptee, 5 adoptive parents, 1 birth parent, 26 social workers, 7 Judges, and 4 Court Administrators.

Questionnaire analysis 
Table 1. Basic parties to terminate adoption questionnaire

\begin{tabular}{|c|c|c|}
\hline Variables & number & Percentage \\
\hline \multicolumn{3}{|c|}{ Adoptee's Gender $(\mathrm{N}=44)$} \\
\hline Male & 20 & 45.5 \\
\hline Female & 24 & 54.5 \\
\hline \multicolumn{3}{|c|}{ Adoptee age when be adopted $(\mathrm{N}=42)$} \\
\hline Less Than 1year old & 8 & 19.0 \\
\hline 1-2 years old & 6 & 14.2 \\
\hline $3-4$ years old & 10 & 23.8 \\
\hline $5-9$ years old & 12 & 28.6 \\
\hline 10-14years old & 3 & 7.1 \\
\hline 15-20years old & 3 & 7.1 \\
\hline \multicolumn{3}{|c|}{ Adoptee age when the adoption terminated $(\mathrm{N}=42)$} \\
\hline Less Than 1year old & 1 & 2.4 \\
\hline 1-2 years old & 1 & 2.4 \\
\hline $3-4$ years old & 0 & 0 \\
\hline $5-9$ years old & 11 & 26.2 \\
\hline 10-14years old & 19 & 45.2 \\
\hline 15-20years old & 10 & 23.8 \\
\hline \multicolumn{3}{|c|}{ Adoption Duration $(\mathrm{N}=42)$} \\
\hline Less Than 1year & 4 & 9.5 \\
\hline $1-2$ years & 11 & 26.2 \\
\hline $3-4$ years & 3 & 7.1 \\
\hline $5-9$ years & 12 & 28.6 \\
\hline $10-14$ years & 8 & 19.0 \\
\hline 15-20years & 4 & 9.5 \\
\hline \multicolumn{3}{|c|}{ The experience of adopted kid $(\mathrm{N}=43)$} \\
\hline None & 41 & 95.3 \\
\hline once & 2 & 4.7 \\
\hline \multicolumn{3}{|c|}{ Adoptee with disease $(\mathrm{N}=43)$} \\
\hline no & 40 & 93.0 \\
\hline yes & 3 & 7.0 \\
\hline \multicolumn{3}{|c|}{ Number of Adoptee's sibling $(\mathrm{N}=43)$} \\
\hline None & 20 & 46.5 \\
\hline One & 11 & 25.6 \\
\hline Two & 6 & 14.0 \\
\hline Three & 4 & 9.3 \\
\hline Four or More & 2 & 4.7 \\
\hline \multicolumn{3}{|c|}{ Adoptive parent's age (father) $(\mathrm{N}=31)$} \\
\hline $26-30$ years old & 5 & 16.1 \\
\hline $31-35$ years old & 6 & 19.4 \\
\hline $36-40$ years old & 5 & 16.1 \\
\hline $41-45$ years old & 7 & 22.6 \\
\hline $46-50$ years old & 2 & 6.5 \\
\hline $51-55$ years old & 4 & 12.9 \\
\hline $56-60$ years old & 2 & 6.5 \\
\hline \multicolumn{3}{|c|}{ Adoptive parent's age (mother) $(\mathrm{N}=23$ ) } \\
\hline 21-25 years old & 1 & 4.3 \\
\hline 26-30 years old & 2 & 8.7 \\
\hline $31-35$ years old & 2 & 8.7 \\
\hline $36-40$ years old & 9 & 39.1 \\
\hline $41-45$ years old & 5 & 21.7 \\
\hline $46-50$ years old & 4 & 17.4 \\
\hline
\end{tabular}




\begin{tabular}{|c|c|c|}
\hline \multicolumn{3}{|c|}{ Marital status when adopting a child (father) $(\mathrm{N}=39)$} \\
\hline Unmarried & 2 & 5.1 \\
\hline Married & 34 & 87.2 \\
\hline Divorced & 1 & 2.6 \\
\hline Widowed & 1 & 2.6 \\
\hline Other & 1 & 2.6 \\
\hline \multicolumn{3}{|c|}{ Marital status when adopting a child (mother) $(\mathrm{N}=30)$} \\
\hline Unmarried & 1 & 3.3 \\
\hline Married & 25 & 83.3 \\
\hline Other & 4 & 13.3 \\
\hline \multicolumn{3}{|c|}{ Marital status when adoption terminated (father) $(\mathrm{N}=39)$} \\
\hline Unmarried & 2 & 5.1 \\
\hline Married & 18 & 46.2 \\
\hline Divorced & 12 & 30.8 \\
\hline Widowed & 1 & 2.6 \\
\hline Cohabit & 1 & 2.6 \\
\hline Other & 5 & 12.8 \\
\hline \multicolumn{3}{|c|}{ Matital status when adoption terminated (mother) $(\mathrm{N}=30)$} \\
\hline Unmarried & 1 & 3.3 \\
\hline Married & 13 & 43.3 \\
\hline Divorced & 5 & 16.7 \\
\hline Cohabit & 2 & 6.7 \\
\hline Other & 9 & 30.0 \\
\hline \multicolumn{3}{|c|}{ Adoptive Parent's Education (father) $(\mathrm{N}=39)$} \\
\hline Less Than Junior High School & 3 & 7.7 \\
\hline Senior High schools & 8 & 20.5 \\
\hline College & 4 & 10.3 \\
\hline Bachelor's Degree & 5 & 12.8 \\
\hline Master's or Doctoral's Degree & 6 & 15.4 \\
\hline Unknown & 13 & 33.3 \\
\hline \multicolumn{3}{|c|}{ Adoptive Parent's Education (mother) $(\mathrm{N}=28)$} \\
\hline Less Than Junior High School & 3 & 10.7 \\
\hline Senior High schools & 5 & 17.9 \\
\hline Bachelor's Degree & 10 & 35.7 \\
\hline Master's or Doctoral's Degree & 1 & 3.6 \\
\hline Unknown & 9 & 32.1 \\
\hline \multicolumn{3}{|c|}{ Adoptive Parent's Occupation (Father) $(\mathrm{N}=39)$} \\
\hline Military and Civil Servants & 2 & 5.1 \\
\hline Business & 5 & 12.8 \\
\hline Industry & 6 & 15.4 \\
\hline Technology Industry & 3 & 7.7 \\
\hline Services & 6 & 15.4 \\
\hline Unemployed & 3 & 7.7 \\
\hline Others & 7 & 17.9 \\
\hline Unknown & 7 & 17.9 \\
\hline \multicolumn{3}{|c|}{ Adoptive Parent's Occupation (Mother) $(\mathrm{N}=30)$} \\
\hline Military and Civil Servants & 3 & 10.0 \\
\hline Business & 5 & 16.7 \\
\hline Services & 4 & 13.3 \\
\hline Unemployed & 4 & 13.3 \\
\hline Housewife & 5 & 16.7 \\
\hline Others & 2 & 6.7 \\
\hline Unknown & 7 & 23.3 \\
\hline
\end{tabular}


Vol.3. No.5 December, 2015, pp. 183-194

\begin{tabular}{|c|c|c|}
\hline \multicolumn{3}{|c|}{ Adoptive Parent's average monthly income (Father) $(\mathrm{N}=37)$} \\
\hline None & 2 & 5.4 \\
\hline 20,000 NT less & 2 & 5.4 \\
\hline $20,001 \sim 30,000 \mathrm{NT}$ & 1 & 2.7 \\
\hline $30,001 \sim 40,000 \mathrm{NT}$ & 5 & 13.5 \\
\hline $40,001 \sim 50,000 \mathrm{NT}$ & 3 & 8.1 \\
\hline 50,001 NT more & 9 & 24.3 \\
\hline Unknown & 15 & 40.5 \\
\hline \multicolumn{3}{|c|}{ Adoptive Parent's average monthly income (Mother)(N=28) } \\
\hline None & 8 & 28.6 \\
\hline 20,000 NT less & 3 & 10.7 \\
\hline $20,001 \sim 30,000 \mathrm{NT}$ & 1 & 3.6 \\
\hline $30,001 \sim 40,000 \mathrm{NT}$ & 3 & 10.7 \\
\hline $40,001 \sim 50,000 \mathrm{NT}$ & 1 & 3.6 \\
\hline 50,001 NT more & 4 & 14.3 \\
\hline Unknown & 8 & 28.6 \\
\hline \multicolumn{3}{|c|}{ Adoptive Parent with other children $(\mathrm{N}=40)$} \\
\hline None & 25 & 62.5 \\
\hline One & 4 & 10.0 \\
\hline Two & 8 & 20.0 \\
\hline Three or more & 2 & 5.0 \\
\hline Unknown & 1 & 2.5 \\
\hline \multicolumn{3}{|c|}{ Birth Parent's Age(Father) $(\mathrm{N}=34)$} \\
\hline Unknown & 18 & 52.9 \\
\hline 26-30 years old & 4 & 11.8 \\
\hline $31-35$ years old & 1 & 2.9 \\
\hline $36-40$ years old & 7 & 20.6 \\
\hline $41-45$ years old & 3 & 8.8 \\
\hline $46-50$ years old & 1 & 2.9 \\
\hline \multicolumn{3}{|c|}{ Birth Parent's Age(Mother) (N=39) } \\
\hline Unknown & 10 & 25.6 \\
\hline $11-15$ years old & 1 & 2.6 \\
\hline $16-20$ years old & 2 & 5.1 \\
\hline $21-25$ years old & 5 & 12.8 \\
\hline $26-30$ years old & 6 & 15.4 \\
\hline $31-35$ years old & 7 & 17.9 \\
\hline $36-40$ years old & 5 & 12.8 \\
\hline $46-50$ years old & 2 & 5.1 \\
\hline $55-60$ years old & 1 & 2.6 \\
\hline \multicolumn{3}{|c|}{ Birth Parent's Marriage(Father) $(\mathrm{N}=33)$} \\
\hline Unmarried & 3 & 9.1 \\
\hline Married & 10 & 30.3 \\
\hline Divorced & 8 & 24.2 \\
\hline Other & 1 & 3.0 \\
\hline Unknown & 11 & 33.3 \\
\hline \multicolumn{3}{|c|}{ Birth Parent's Marriage(Mother) (N=39) } \\
\hline Unmarried & 9 & 23.1 \\
\hline Married & 17 & 43.6 \\
\hline Divorced & 7 & 17.9 \\
\hline Cohabit & 1 & 2.6 \\
\hline Others & 2 & 5.1 \\
\hline Unknown & 3 & 7.7 \\
\hline
\end{tabular}




\begin{tabular}{|c|c|c|}
\hline \multicolumn{3}{|c|}{ Birth Parent's Education(Father) (N=37) } \\
\hline Less Than Junior High School & 5 & 13.5 \\
\hline Senior High schools & 4 & 10.8 \\
\hline Bachelor's Degree & 2 & 5.4 \\
\hline Unknown & 26 & 70.3 \\
\hline \multicolumn{3}{|c|}{ Birth parent's education(Mother) $(\mathrm{N}=39)$} \\
\hline Less Than Junior High School & 10 & 25.6 \\
\hline Senior High schools & 6 & 15.4 \\
\hline College & 2 & 5.1 \\
\hline Bachelor's Degree & 4 & 10.3 \\
\hline Unknown & 17 & 43.6 \\
\hline \multicolumn{3}{|c|}{ Birth parent's occupation (Father) $(\mathrm{N}=38)$} \\
\hline Military and Civil Servants & 1 & 2.6 \\
\hline Business & 1 & 2.6 \\
\hline Industry & 5 & 13.2 \\
\hline Services & 2 & 5.3 \\
\hline Others & 5 & 13.2 \\
\hline Unknown & 24 & 63.2 \\
\hline \multicolumn{3}{|c|}{ Birth parent's occupation (Mother) $(\mathrm{N}=40)$} \\
\hline Business & 2 & 5.0 \\
\hline Industry & 2 & 5.0 \\
\hline Technology Industry & 1 & 2.5 \\
\hline Services & 5 & 12.5 \\
\hline Unemployed & 5 & 12.5 \\
\hline Housewife & 6 & 15.0 \\
\hline Others & 9 & 22.5 \\
\hline Unknown & 10 & 25.0 \\
\hline \multicolumn{3}{|c|}{ Birth parent's average monthly income (Father) $(\mathrm{N}=35)$} \\
\hline 20,000 NT less & 2 & 5.7 \\
\hline $20,001 \sim 30,000 \mathrm{NT}$ & 3 & 8.6 \\
\hline $30,001 \sim 40,000 \mathrm{NT}$ & 1 & 2.9 \\
\hline $40,001 \sim 50,000 \mathrm{NT}$ & 3 & 8.6 \\
\hline 50,001 NT more & 1 & 2.9 \\
\hline Unknown & 25 & 71.4 \\
\hline \multicolumn{3}{|c|}{ Birth parent's average monthly income (Mother) $(\mathrm{N}=40)$} \\
\hline None & 12 & 30.0 \\
\hline 20,000 NT less & 5 & 12.5 \\
\hline $20,001 \sim 30,000 \mathrm{NT}$ & 5 & 12.5 \\
\hline $30,001 \sim 40,000 \mathrm{NT}$ & 1 & 2.5 \\
\hline $40,001 \sim 50,000 \mathrm{NT}$ & 2 & 5.0 \\
\hline 50,001 NT more & 2 & 5.0 \\
\hline Unknown & 13 & 32.5 \\
\hline
\end{tabular}

Table 2. The statistical analysis of adoption reason for birth parents

\begin{tabular}{|c|c|c|}
\hline The adoption reason for birth parents & number & $\mathrm{N}=44$ (multiple responses) \\
\hline Others & 27 & $61.4 \%$ \\
\hline Illegitimate child & 12 & $27.3 \%$ \\
\hline Economic factors & 12 & $27.3 \%$ \\
\hline Inability to take care of child & 9 & $20.5 \%$ \\
\hline Orphans, no father and mother & 2 & $4.5 \%$ \\
\hline Abandoned baby & 1 & $2.3 \%$ \\
\hline Abandonment, severe neglect, abuse and declared by the court order to terminate parents right & 1 & $2.3 \%$ \\
\hline
\end{tabular}


Table 3. The adoption dissolution statistical analysis of adoptee personal factors

\begin{tabular}{|c|c|c|}
\hline Adoptee personal factors & number & $\mathrm{N}=44$ (multiple responses) \\
\hline Others & 17 & $38.6 \%$ \\
\hline Children with difficulty in establishing relationships with adoptive family & 14 & $31.8 \%$ \\
\hline Children with older age & 5 & $11.4 \%$ \\
\hline Children with behavior problem & 5 & $11.4 \%$ \\
\hline Children with difficulty leaving his birth home & 5 & $11.4 \%$ \\
\hline Children with emotional problems & 4 & $9.0 \%$ \\
\hline Children with other special needs & 2 & $4.5 \%$ \\
\hline $\begin{array}{l}\text { Children information which adoption agency failed to provide adoptive parent } \\
\text { completely }\end{array}$ & 2 & $4.5 \%$ \\
\hline Children with many experiences in different foster families before the adoption & 1 & $2.3 \%$ \\
\hline
\end{tabular}

Table 4. The adoption dissolution statistical analysis of adoptive family factors

\begin{tabular}{|c|c|c|}
\hline Adoptive family factors & number & N=44(multiple responses) \\
\hline Others & 22 & $50.0 \%$ \\
\hline Adoptive parents' marital relationship is unstable & 15 & $34.1 \%$ \\
\hline Adoptive parent cannot accept the adoptee's performance behavior & 9 & $20.5 \%$ \\
\hline Adoptive parents' poor parenting & 6 & $13.6 \%$ \\
\hline Adoptive parents' personality issue & 6 & $13.6 \%$ \\
\hline Adoptive parents without parenting experience & 5 & $11.4 \%$ \\
\hline Infertility is not the motivation for adoption & 4 & $9.0 \%$ \\
\hline Adoptive parents requirements too high to the child & 4 & $9.0 \%$ \\
\hline Adoptive father involving less parenting & 4 & $9.0 \%$ \\
\hline Adoptive mother was pregnant after adoption & 3 & $6.8 \%$ \\
\hline Adoptive parents cannot afford the finances after the adoption & 3 & $6.8 \%$ \\
\hline Adoptive parents can not meet the child needs & 2 & $4.5 \%$ \\
\hline Adoptive parents did not know the adoptee completely before adoption & 2 & $4.5 \%$ \\
\hline The adoption was required or forced by the elders of one or both adoptive parents & 2 & $4.5 \%$ \\
\hline Adoptive mother unable to provide the child's care & 2 & $4.5 \%$ \\
\hline
\end{tabular}

Table 5. The adoption dissolution statistical analysis of adoption agencies factors

\begin{tabular}{|c|c|c|}
\hline Adoption agencies factors & number & N=44(multiple responses) \\
\hline Others & 5 & $11.4 \%$ \\
\hline Adoption agencies cannot meet the needs of adoptive families & 4 & $9.0 \%$ \\
\hline Adoption agencies did not provide complete information to adoptive family & 3 & $6.8 \%$ \\
\hline $\begin{array}{c}\text { Adoption agencies failed to provide enough resources or services, also did not } \\
\text { consider the current situation of adoptive family }\end{array}$ & 2 & $4.5 \%$ \\
\hline $\begin{array}{c}\text { Adoption agencies with poor professional matchmaking } \\
\text { family }\end{array}$ & 1 & $2.3 \%$ \\
\hline $\begin{array}{c}\text { Adoption agencies failed to provide a complete service to support adoptive } \\
\text { Adoption agencies' staffs over-commitment }\end{array}$ & 1 & $2.3 \%$ \\
\hline Adoption agencies' staffs instability, resulting in inconsistent service & 1 & $2.3 \%$ \\
\hline
\end{tabular}




\section{Qualitative analysis}

The risk factors of adoption dissolution

According to the respondents of Court Administrator there are four types of adoption dissolution: 1. step-parent adopt child when parents married, step-parent adopt dissolution when parents divorced. 2. Children with behavior problem 3 . Children with difficulty in establishing relationships with adoptive family. 4. Adoptive parents unable to take care of the child (Court Administrator 1; Court Administrator 2).

\section{The adoptee factors}

1. The adoptee with delinquent behavior

Much adoption dissolution occured after the adoptee exhibited delinquent behavior. (Social worker 21)

2. The older the age of the adoptee, the greater the chances of adoption dissolution

Whether it is national or international adoption, the greater the age of the adoptee, the greater the chances of adoption dissolution. (Social worker 7)

3. To assist the adoptee to adapt

Children who changed many environments, especially children in foster care, experience more difficulties in establishing a relationship with the adoptive family. (Social worker 10)

\section{If adoptee is attached to the birth family, it is difficult to establish attachment with adoptive families}

One summer vacation, she wanted to contact her biological father and she wanted to be with her father. And I said, yes. After all, she is his daughter. (Adoptive parent 2)

\section{The birth telling}

If no one talks to the adoptee about the adoption, when the adoptee finds out that he was adopted by himself, it is possible for his whole personality to change, causing him to be unable to behave well. (Court Administrator 3)

\section{The birth family fantasy and expectations}

He found that he was an adopted child, and he wanted to find his family. Finally, he found his own brother, however the brother took him to steal! (Judge7)

\section{Adoptive family factors}

\section{The philosophy of adoption}

My husband told me to say that the adoptee is my biological child, but I do not want to do that. (Adoptive parent 3)

My birth father sold me to my adoptive mother. And she bought me, she might want to me to look after her when she is getting old. (Adoptee1)

\section{Stepparent adoption}

Some stepparents adopt a child after marriage so as to make the kids have a sense of belonging. (Court Administrator 2)
Like some mothers remarried, and they required kids to be adopted by the step father, also to change the surname. Once remarried, the kid was adopted and changed the surname. (Court Administrator 2)

\section{Surname change}

Some children's voices, my mother has been remarried, he felt annoyed that this has led to a change of surname. (Court Administrator 4)

\section{The parenting capacity of adoptive family}

She was not a mother, she was like ... I was her accessories. And she controlled me and she did not care for me. When I was 10 years old, and I was alone and seriously sick, no one rescued me. (Adoptee1)

\section{Adoptive parents unable to discipline the adoptee}

When the adoptee studied junior high school, and he became difficult and impossible to be disciplined by adoptive parents, the adoptive parents maybe went to court to terminate the adoption. (Social worker 11)

\section{Re-adoption with high-risk}

We all thought that with the early success of raising a child, they would be good parents for the re-adoption. However, we found that re-adoption has a very high failure rate, there may be the reason that because at first the adoptee behaved very well, they then thought that it would be easier with the second adoptee. (Social worker 7)

\section{Adoptive mother was pregnant after adoption}

Suddenly, the adoptive mother was pregnant after adoption. (Social worker 6)

\section{No ideas about birth telling}

Adoptive parents had lots of excuses in birth telling such as that, children too young to do it! Later and later, they just escape and avoid to talking about it. (Social worker 12)

She (the adoptee) might know a little about the adoption. I guess. (Adoptive parent 3 )

\section{Birth parent factors}

1. The inability to take care of kids

Mom reported to the Social Department and said that she did not have the ability to raise his children, please help her. (Adoptive parent 2)

\section{The dependent behavioral factors}

Mother's life is relatively indiscrete, she had a cohabiting boyfriend. Also, she had several children, and she asked me if she could borrow money. (Adoptive parent 2)

\section{The time for adoption}

She was not really ready to be a mother. We helped her to think careful and to look after her kid by herself. We tried for almost two years, the mother was still unstable, finally she believed that she was not ready to be a mother. (Social worker 18) 


\title{
The adoptive agency factors
}

1. fully communicate the message or not

Have to be very careful, especially in the medical information in the context of child care as well as we will collect is very wide, so it will not even behavioral problems in some children we will be very really speaking like this, so he came as a surprise when he could not accept. (Social worker 10)

2. The organization of long-term companionship

Our service is not to say the end of this adoption case, my institutions might 20 or30 years are possible, the service you provide may 20 or 30 in such a long period of time. (Social worker 22)

3. The agency report quality

Sometimes I will ask my social workers to write more objectively, because the report might be effected the judgement. (Social worker 18)

\section{Discussion : Dispute Resolution?}

In order to avoid adoption disruption or adoption dissolution, which may cause adoptees physical and mental harm, some countries have developed interstate adoption mediation in recent years (Jasper, 2008; Macrac, 2006; Maynard, 2005). Family mediation presents the most efficient way to provide adoptees with an appropriate environment for a permanent and stable life (Foli \& Thompson, 2004).

\section{Conclusions}

\begin{abstract}
The risk factors of adoption dissolution included:
A. adoptee characteristics: older age, emotional and behavioral disorder, sibling separation, special needs, poor health, difficulty in attachment, many placements before adoption.

B. adopter family characteristics: their elders force them to adopt kids, too high expectation for kid's performance, lack of parenting skills, lack of caring experience, unstable marriage, pregnancy after adoption, negative personality, financial problems, misconceptions of adoption, adoptive father helping less in caring, step parent adoption, surname change, adopting other kids again

C. agency characteristics: unprofessional in matching, insufficient service quality and assistance, unfit family needs, inadequate information.
\end{abstract}

The research found that most of minor child adoption dissolution is through private adoption. The understanding of adoption is still conservative and traditional, and focuses on adults' themselves in Taiwan. Thus, the Government and adoption agencies should actively provide assistance for adoption, and make available and accessible post-adoption supportive services to protect the best interests of the child.

\section{REFERENCES}

Barth, R. P., \& Berry, M. (1991). Preventing adoption disruption. Prevention in Human Services, 9 (1), 205-222.

Barth, R. P., Berry, M., Yoshikami, R., Goodfield, R. K., \& Carson, M. L. (1988). Predicting adoption disruption. Social Work, 33 (3), 227-233.

Barth, R. P., \& Miller, J. M. (2000). Building effective post adoption services: What is the Empirical Foundation Family
Relations, 49 (4), 447-455.

Chen, R. J. \& Wang, C. C. (2003). The adoption profiles and changed in Taipei. Child Welfare Journals, 5,17-36.

Cruz, M. (2011). International adoptions result in discrimination. In Chenes, E. D. (ed). International Adoptions (pp.111-117). MI: Greenhaven Press.

Coakley, J.F., \& Berrick, J.D. (2008). Research review: In a rush to permanency: preventing adoption disruption. Child \& Family Social Work, 13 (1), 101-112.

Deng, X. R. (2007). The parent-child relationship after Family Law amendment. The Taiwan Law Review, 146,148-159.

Faller, K. C. (2000). Individual change in children and direct social work practice. In Paula, A. M. \& Garvin, C. D. (eds) The Handbook of Social Work Direct Practice London: Sage.

Festinger, T. (2002). After adoption- dissolution or permanence. Child Welfare, 81 (3), 515-533.

Foli, K. J. \& Thompson, J. R. (2004). The post-adoption blues: Overcoming the unforeseen challenges of adoption. USA: Rodale 
Inc.

Gray, D. D. (2002). Attaching in adoption- practical tools for today's parents. IN: Perspectives Press, Inc.

Jasper, M. C. ( 2008). The law of adoption. NY: Oxford University Press, Inc.

Jiang Y. Y. (2011). Legal adoption study in Taiwan. Chung Cheng University Institute of Law Master's thesis.

Lai, Y. M. (2014a). Wish children have homes- Taiwan received a support system for a new look. Chinese Culture Social Welfare Foundation and Harbin Institute of Technology, 2014 Symposium on both sides of the social welfare. Mainland China: Harbin Institute of Technology.

Lai, Y. M. (2014b). Stepparent adopt kid when parents married, stepparent adopt dissolution when parents divorced: The research of adoption dissolution in Taiwan.

Lai, Y. M. (2010). The preparation educational courses for adoptive parental parenting. Research commissioned by the Ministry of Children's Bureau.

Lee, R. J. (2002). Substitute child welfare services. Fifty years of child welfare in Taiwan. Taichung: Children's Bureau.

Lin, J. C. (1996). Family Law. Taipei: Wunan Bookstore.

Liu, J. G. (2008). Adoptive son sued rush out. 2008.10.10 BBC News website. Taken

http://tw.myblog.yahoo.com/jw!ga9p9iuTQE7N63sfElEW3C5yw g--/article?mid=23319, Internet Date: 2011.05.29.

Macrac, S. (2006). Disruption and dissolution: unspoken losses. In Macleod, J. \& Macrae, S (eds) Adoption parenting: Creating a toolbox, building connections, (pp.195-202). New Jersey: EMK Press.

Maluccio, A. N. (2000). What works in family reunification. In Kluger, M.P., Alexander, G. \& Curtis, P. A. (eds.) What Works in Child Welfare (pp.163-170). Washington: CWLA Press.

Masson, J. (2009). Child protection. In Montgomery, H. \& Kellett, M. (eds) Children and Young People's Worlds- Developing Frameworks for Integrated Practice (pp.145-164). UK: The Open University.

Maynard, J. (2005). Permanency mediation: A path to open adoption for children in out-of-home care. Child Welfare: Journal of Policy, Practice and Program, 84, 507-526.

McCreight, B. (2002). Parenting your adopted older child-How to overcome the unique challenges and raise a happy and healthy child. CA: New Harbinger Publications, Inc.

McDonald, T. P., Lieberman, A. A., Partridge, S., \& Hornby, H.
(1991). Assessing the role of agency services in reducing adoption disruptions. Children and Youth Services Review, 13 (5-6), 425-438.

McRoy, R. G., Lynch, C. J., Chanmugam, A., Madden, E. \& AyersLopez, S. (2009). Children from care CAN be adopted. In Wrobel, G. M. \& Neil, E. (eds) International Advances in Adoption Research for Practice (pp.97-118). West Sussex: John Wiley \& Sons Ltd.

Pecora, P. J. (2006). Chile welfare policies and programs. In Jenson, J. M. \& Fraser, M. M. (eds) Social Policy for Children \& FamiliesA Risk and Resilience Perspective (pp. 19-66). London: Sage Publications.

Pecora, P. J. \& Maluccio, A. N. (2000). What works in family foster care. In Kluger, M.P., Alexander, G. \& Curtis, P. A. (eds) What Works in Child Welfare (pp.139-156). Washington: CWLA Press.

Rosenthal, J. A. (1993). Outcomes of adoption of children with special needs. The Future of Children, 3 (1), 77-88.

Rosenthal, J. A., Schmidt, D., \& Conner, J. (1988). Predictors of special needs adoption disruption: An exploratory study. Children and Youth Services Review, 10 (2), 101-117.

Scherr, M. I. (2001). Child Welfare Service Development in USA, presented in Growth and Integration-International Conference on NPO and Child Welfare in the 21th Century. Taipei: Child Welfare League Foundation.

Schmidt, D. M., Rosenthal, J. A., \& Bombeck, B. (1988). Parents' views of adoption disruption. Children and Youth Services Review, $10(2), 119-130$.

Schooler, J. E. \& Atwood, T. C. (2008). The whole life adoption book-Realistic advice for building a health adoption family. CO: NavPress

Schwartz, L. L. (2006). When adoptions go wrong- psychological and legal issues of adoption disruption. NY: The Haworth Press, Inc.

The Swedish National Board of Health and Welfare (2009). Adoption- Handbook for the Swedish social service.

Triseliotis, J., Shireman, J. \& Hundleby, M. (1997). Adoption-Theory, Policy and Practice. London: Cassell.

Valdez, G. M. \& McNamara, J. R. (1994). Matching to prevent adoption disruption. Child and Adolescent Social Work Journal, 11 (5), 391-403.

Westhues, A. \& Cohen, J. S. (1990). Preventing disruption of special-needs adoptions. Child Welfare, 69 (2), 141-155.

Wang H. N. (2007). The amendment of the Family Law provisions on the adoption. The Taiwan Law Review, 148,196-211. 